\author{
Zbigniew Drozdowicz \\ Uniwersytet im. Adama Mickiewicza, Poznań \\ ORCID: 0000-0001-9409-9029 \\ e-mail:drozd@amu.edu.pl
}

\title{
Sumienie według oświeceniowych filozofów
}

Dosyć powszechne jest przekonanie, że w naszym myśleniu, mówieniu i praktycznym postępowaniu powinniśmy kierować się sumieniem. Sprawa zaczyna się komplikować w momencie, kiedy przychodzi nam odpowiedzieć na pytania, czym to sumienie jest $\mathrm{i}$ jakie jest oraz czy może i powinno być doskonalone, a jeśli tak, to przez kogo i w jaki sposób. Lista pytań nie ogranicza się wyłącznie do tych kilku zagadnień, jednak już nawet te, które zostały tutaj przedstawione, pozwalają zobaczyć, jak dużą złożonością cechuje się ten problem. Rozłożenie go na proste składowe oczywiście jest możliwe, ale trzeba liczyć się z tym, że każda z tych składowych może generować kolejne pytania. W tych rozważaniach nie podejmę próby ani sporządzenia pełnej listy takich zasadniczych pytań dotyczących sumienia, ani tym bardziej udzielenia na nie definitywnych odpowiedzi. Tytułowy problem zawężam do sumienia, o którym mówili tacy znaczący przedstawiciele epoki Oświecenia, jak: Immanuel Kant, Adam Smith, Voltaire i Paul Tiry Holbach. Różnili się oni w niejednym punkcie $\mathrm{w}$ jego pojmowaniu i kierowaniu się nim w swoim myśleniu, w mówieniu i w praktycznym postępowaniu. Zgodni jednak byli co do tego, że sumienie powinno być oświecone. U każdego z nich oznaczało to swoiste votum separatum wobec tych sposobów jego pojmowania i przedstawiania, które pojawiały się $\mathrm{w}$ przedoświeceniowej tradycji chrześcijańskiej, w szczególności wobec traktowania go jako daru Bożego i uzależniania go od boskiej woli ${ }^{1}$.

1 „Sumienie to ów moment w doświadczeniu wolności przez człowieka, w którym uświadamia on sobie swą odpowiedzialność. Biblia posługuje się w tym 


\section{Kantowskie ujmowanie sumienia}

Wprawdzie już w czasach Odrodzenia zostały podjęte próby wskazania różnicy i granicy między teologią i filozofia, jednak były one wówczas dosyć nieśmiałe (żeby nie powiedzieć: bojaźliwe). W miarę upływu czasu stawały się one jednak coraz odważniejsze, a w XVIII stuleciu pojawili się w Europie Zachodniej myśliciele, którzy otwarcie deklarowali, że nie chca, aby ich filozofia miała coś wspólnego $\mathrm{z}$ teologia, a nawet $\mathrm{z}$ tą filozofia, która szła z nią na kompromisy. Nie byli oni wówczas bardzo liczni. Okazali się jednak na tyle przekonywający, że z czasem nie tylko powiększały się ich szeregi, ale także wpływy w zachodniej kulturze. Swoich zwolenników zyskiwali jednak również ci, którzy uważali, że można, a nawet należy, znaleźć racjonalny kompromis między filozofią i teologią. Warunkiem jest jednak, aby zarówno ta pierwsza, jak i ta druga były oświecone.

Jednym z bardziej znaczących zwolenników takiego kompromisu był Immanuel Kant (1724-1804). Odpowiedź na pytanie, co to oznaczało w jego filozofii, może być zarówno w miarę prosta, jak i dosyć złożona. W miarę prosta będzie ona wówczas, jeśli podążymy za Kantowskim wskazaniem, "czym jest Oświecenie”. Przypomnę krótko, że w jego świetle

Oświecenie to wyjście człowieka z zawinionej przez niego niedojrzałości. Niedojrzałość jest nieumiejętnością w posługiwaniu się własnym rozumem, bez przewodnictwa innych. Niedojrzałość ta jest zawiniona przez człowieka, jeśli jej powód tkwi nie w braku rozumu, ale zdecydowania i odwagi, by swym rozumem posługiwać się bez zwierzchnictwa innych.

przypadku pojęciem serca, w którym wpisana jest wola Boża [...]. Ten, kto działa z wewnętrznego przekonania, to znaczy w posłusznym uznaniu rzeczywistości, która jest uprzednia w stosunku do wolności, a nawet implicite przeciwstawia się jej niekiedy, ma czyste sumienie i będzie oglądał Boga". Karl Rahner, Herbert Vorgrimler, Mały słownik teologiczny, przeł. Tadeusz Mieszkowski, Paweł Pachciarek (Warszawa: Instytut Wydawniczy Pax, 1987), 438 i n. O tym, że sumienie stanowi dar Boży, mowa jest choćby w książce ks. Włodzimierza Zatorskiego. Jej autor przywołuje w niej między innymi ewangeliczne tradycje w jego pojmowaniu i przedstawianiu. Przypomina w niej również wezwanie św. Augustyna: „Przyjmij dar sumienia”, oraz powołuje się na refleksję Jana Pawła II z encykliki o Duchu Świętym - Dominum et vivificantem. $\mathrm{Na}$ tej podstawie formułuje generalizujące twierdzenia, że „sumienie jest słuchem serca prowadzącym do nawrócenia. Nie tylko ocenia nasze postępowanie, ale jego głos jest wezwaniem do przemiany serca. [...] Odkryć sumienie oznacza poznać prawdę dotyczącą naszego życia. Prawdę, że jest ono nie na naszą ludzką miarę, ale na miarę Boga”, , prawdziwe sumienie kształtuje Duch Święty. Stąd wynika oczywisty wniosek: jedyne, co możemy zrobić z naszej strony, aby stać się ludźmi sumienia, to otworzyć się na Niego i Jego działanie w nas". Włodzimierz Zatorski (OSB), Dar Sumienia (Kraków: Wydawnictwo Benedyktynów, 2006), 7. 
Sapere aude! - Odważ się posługiwać własnym rozumem - stanowi maksymę przewodnią oświecenia ${ }^{2}$.

Dalej pojawia się szereg takich stwierdzeń, które w zamyśle ich autora mają rozjaśniać obraz tego kompromisu, jednak dla niejednego z czytelników tego pisma mogły i mogą stanowić spore utrudnienie $\mathrm{w}$ jego trafnym zrozumieniu, a nawet postawić w kłopotliwej sytuacji jego sumienie. Czyż bowiem nie może go postawić w takiej sytuacji wskazywanie przez Kanta na ludzki oportunizm jako przyczynę braku odwagi i zdecydowania, czy też wskazywanie na takich naszych „opiekunów", którzy raczej zainteresowani są utrzymaniem naszego umysłu „w kajdanach ciągłej niedojrzałości" niż uwalnianiem go z nich (w tym gronie można znaleźć nie tylko księży, ale także urzędników, a nawet niektórych uczonych). Trzeba oczywiście pamiętać o okolicznościach napisania w 1784 roku tego krótkiego szkicu (trwały wówczas spory uniwersyteckich uczonych z władzami Prus o ich prawo do wolności w zakresie prowadzonych badań i głoszenia swoich poglądów).

Te wypowiedzi Kanta, które pojawiały się w tak zwanym okresie krytycznym jego rozwoju intelektualnego, stanowią nie tylko jego wizytówkę, ale także punkt wyjścia do zrozumienia wszystkich napisanych w tym czasie dzieł. Ich listę otwiera opublikowana w 1781 roku Krytyka czystego rozumu. Trzeba wyraźnie powiedzieć, że nie jest to lektura ani dla amatorów filozoficznych dywagacji, ani nawet dla tych oświeceniowych filozofów, którzy gustowali w publicystyce i eseistyce. Rzecz nawet nie tyle $w$ tym, że jej autor miał kłopoty z jasnym i konsekwentnym wyłożeniem swoich poglądów, ile $\mathrm{w}$ tym, że uznał, iż trzeba przejść krok po kroku i etap po etapie całą drogę filozoficznego myślenia, którą on sam pokonał. Punktem wyjścia są w niej te „pytania, które dręczą ludzki rozum i których nie może on pominąć, bowiem zadaje mu je jego własna natura”, poprzez „staczanie się w mrok sprzeczności” ${ }^{3}$. Następnie dochodzi do wydobywania się z niego i znajdowania w końcu tej jasności, której osiągnięcie było pragnieniem wielu pokoleń filozofów i uczonych - niestety tylko pragnieniem, jako że w momencie, gdy wydawało im się, że ową jasność osiągnęli, okazywało się, że wciąż tkwią w sprzecznościach. Na sporządzonej przez Kanta liście filozofów znajdują się takie znakomitości czasów starożytnych jak Platon, Arystoteles i Epikur, a także tacy wielcy myśliciele czasów nowożytnych jak Kartezjusz, John Locke, Gottfried Wilhelm Leibniz i David Hume.

${ }^{2}$ Immanuel Kant, Odpowiedź na pytanie: czym jest oświecenie, w: tenże, Rozprawy z historii filozofii, przeł. Tomasz Kupś (Kęty: Wydawnictwo Antyk, 2005), 44.

${ }^{3}$ Immanuel Kant, Krytyka czystego rozumu, t. 1, przeł. Roman Ingarden (Warszawa: PWN, 1957), 7. 
Nie miejsce tutaj ani na szczegółową prezentację zarzutów stawianych przez Kanta tym filozofom, ani też na przedstawienie całej drogi Kantowskiego myślenia, która doprowadziła go do wyartykułowania oświeconego sumienia nazwanego przez filozofa imperatywem kategorycznym. Warto powiedzieć przynajmniej tyle, że pojawia się on $\mathrm{w}$ jego filozofii moralnej, stanowiącej logiczną pochodną filozofii czystego rozumu oraz część składową rozumu praktycznego. Odpowiedź na pytanie, jak należy rozumieć te zależności i związki oraz co ów imperatyw oznacza, znajduje się we wprowadzeniu do Metafizyki moralności. Kant stwierdza tam, że:

czysty rozum, będąc instancją prawodawcza, dostarcza pryncypiów praktycznych skierowanych do woli arbitralnej - przy tym abstrahują one zawsze od interesującego ją przedmiotu; rozum nie zajmuje się bowiem materialną stroną prawa, lecz tylko i wyłącznie formą, dzięki której arbitralna maksyma woli arbitralnej zdatna jest do tego, aby stać się prawem powszechnym. [...] Ponieważ ludzkie maksymy odznaczają się charakterem nieustannie subiektywnym i jako takie nie okazują się same przez się maksymami obiektywnymi, przeto rozum musi tę naczelną zasadę przepisywać pod postacią nieznoszącego sprzeciwu nakazu lub zakazu, znanego jako imperatyw nakazu bądź też zakazu .

Zagadnienie to wygląda dosyć zawile, jednak w dalszej części traktatu Kant starał się przedstawić je w bardziej przystępny sposób. Okazuje się bowiem, że wiele tych kwestii można zredukować do trzech podstawowych zaleceń: 1 . „działaj tylko zgodnie z tą maksymą dzięki czemu możesz jednocześnie chcieć, aby to prawo stało się prawem powszechnym"; 2. działaj w taki sposób, aby traktować człowieka nie jako środek do celu, lecz jako cel sam w sobie; 3 . działaj tak, abyś mógł myśleć o sobie jako o „członku uniwersalnego królestwa celów”.

W końcowych partiach traktatu pojawia się odpowiedź na pytanie, co to jest sumienie. Według Kanta "tkwi ono od samego początku w każdym człowieku jako istocie moralnej" $\mathrm{i}$, jest w zasadzie tożsame $\mathrm{z}$ rozumem praktycznym". Udziela on również odpowiedzi na pytanie, jak się ma ono do imperatywu kategorycznego. Filozof uważa, że to „obiektywny przymus [wynikający] z mocy samego prawa" i ,jako taki należy do praktycznej domeny intelektu". W rozwinięciu tych odpowiedzi Kant stwierdza, że „sumienie posiada każdy człowiek: przed obserwującym go od wewnątrz sędzią odczuwa on respekt i lęk przeplatający się z szacunkiem. Ta czuwająca nad nim oraz jego prawem władza nie jest czymś ustanowionym przezeń dobrowolnie, lecz organiczną częścią

${ }^{4}$ Tenże, Metafizyka moralności, przeł. Ewa Nowak (Warszawa: Wydawnictwo Naukowe PWN, 2005), 18. 
jego istoty" ${ }^{\prime \prime}$. Jeśli ktoś postępuje zgodnie z zaleceniami sumienia, to być może będzie przeżywał jakieś rozterki intelektualne, ale nie moralne. Te ostatnie pojawią się jednak wówczas, gdy nie będzie przestrzegał któregoś z wymienionych wyżej zaleceń.

\section{Smithowskie ujmowanie sumienia}

Ważnym głosem w dyskusji na temat pojmowania i przedstawiania sumienia przez oświeceniowych filozofów są również poglądy Adama Smitha (1723-1790). Oczywiście można z nimi polemizować. Trudno jednak zakwestionować fakt, że dzieło zatytułowane Badania nad natura i przyczynami bogactwa narodów (1776) zawiera takie założenia i postulaty, które dzisiaj należą do elementarza kapitalistycznego pojmowania rynku i gospodarki rynkowej. Bez większego trudu można jednak w nim znaleźć również założenia i postulaty wykraczające poza tę teorię ekonomiczną i wkraczające na grunt filozofii, która w centrum swojego zainteresowania ma człowieka - zarówno mniej, jak i bardziej zaradnego gospodarczo, w każdym przypadku jednak żywotnie zainteresowanego losem swoim i swoich najbliższych. Na fundamentalne pytanie, czym się kieruje ten człowiek w swoim życiu i we współżyciu z innymi, odpowiedź Smitha nie pozostawia zbyt wiele miejsca na mówienie o chrześcijańskim altruizmie. Wynika z niej bowiem jasno, że kieruje się on swoim egoizmem i - co nie mniej istotne - powinien się nim kierować, jeśli chce, aby zaspokojone zostały zarówno jego potrzeby, jak i potrzeby tych, z którymi przyszło mu współżyć i współpracować w wytwarzaniu różnorakich dóbr. Dlaczego? A no dlatego, że

człowiek prawie zawsze potrzebuje pomocy swoich bliźnich i na próżno szukałby jej jedynie w ich życzliwości. Jest bardziej prawdopodobne, że nakłoni ich do pomocy, jeśli potrafi przemówić do ich egoizmu i pokazać im, że dla nich samych korzystne jest, by zrobili to, czego od nich żąda. Każdy, kto proponuje drugiemu jakiś interes, postępuje $\mathrm{w}$ ten sposób. [...] [Zatem] [...] nie od przychylności rzeźnika, piwowara czy piekarza oczekujemy obiadu, lecz od ich dbałości o własny interes. Zwracamy się nie do ich humanitarności, lecz do egoizmu, i nie mówimy im o naszych potrzebach, lecz o ich korzyściach. Jedynie żebrak godzi się z tym, aby zależeć głównie od łaski współobywateli'

W dziele tym można znaleźć szereg bardzo szczegółowych wskazań, jak powinien postępować obywatel, aby jego interes „dobrze się kręcił”,

5 Tamże, 315.

${ }^{6}$ Adam Smith, Badania nad natura i przyczynami bogactwa narodów, t. 1, przeł. Oswald Einfeld, Stefan Wolff (Warszawa: PWN, 1954), 20. 
a przynajmniej aby jego bilans strat i zysków był na plusie. Wszystko to składa się nie tylko na jego teorię racjonalnego gospodarowania, ale także na jego praktykę. Natomiast stosunkowo niewiele mówi się tam o moralności, a jeszcze mniej o sumieniu.

Kwestiom tym poświęcona jest jednak opublikowana w 1759 roku Teoria uczuć moralnych. Wprawdzie oświecone sumienie nie pojawia się $\mathrm{w}$ niej $\mathrm{w}$ pierwszoplanowej roli - ta przypadła $\mathrm{w}$ udziale różnorakim i różnorodnym uczuciom moralnym (takim jak sympatia czy uczucia egoistyczne) - jednak w momencie, gdy Smithowi przychodzi odpowiedzieć na pytanie o ich wewnętrzne źródło, wskazuje on na sumienie. Najpierw występuje ono w roli „wyrzutów sumienia” (,wyrzuty sumienia ze wszystkich uczuć są najstraszniejsze") i łączone jest z takimi stanami emocjonalnymi jak "poczucie wstydu”, „współczucia dla tych, którzy ucierpieli”, oraz „przerażenia i obawy przed karą"”. Później pojawia się jako sprawca odwoływania się do "nieba" i dziękowania mu za "uratowania go [człowieka] od tej winy, w którą był gotów się wplątać", a gdy już się $\mathrm{w}$ nią wplątał $\mathrm{i}$,pogwałcił wszelkie zasady postępowania, które mogłyby uczynić go miłym dla ludzi”, jako sprawca "męki i przerażenia”, że „istnieje Bóg, który to pomści”. Jeszcze później pojawia się W roli tego „najwyższego trybunału”, którego głos nawołuje, „by stać się godnym pochwały” lub przynajmniej „nie zasługiwać na naganę”. Już nawet na podstawie tej mocno skróconej prezentacji Smithowskiej teorii sumienia można z pełnym przekonaniem powiedzieć, że nie tylko nie brała ona całkowitego rozbratu z jego chrześcijańskim pojmowaniem, ale wręcz przejmowała niejedno z jego istotnych założeń i postulatów, w tym założenie, że Bóg istnieje i może upomnieć się o przestrzeganie narzuconych przez siebie nakazów i zakazów. Skłania to niektórych interpretatorów poglądów Smitha do traktowania ich jako chrześcijańskiej teologii ${ }^{8}$.

\section{Wolterowskie ujmowanie sumienia}

To kwestia wątpliwa, aby Voltaire (1694-1778) miał jakiś wpływ na poglądy Kanta czy Smitha. Długa jest jednak lista tych filozofów (i nie tylko ich), którzy po zapoznaniu się z którymś z jego traktatów lub filozoficznych powiastek poczuli się na tyle oświeceni, aby nabrać poważnych wątpliwości nie tylko wobec zasadności chrześcijańskich wierzeń i praktyk, ale także względem prawości tych sług Bożych, którzy przez wieki

7 Adam Smith, Teoria uczuć moralnych, przeł. Danuta Petsch (Warszawa: PWN, 1989), $125 \mathrm{i} \mathrm{n}$.

${ }^{8}$ Luis Hill, "The hidden theology of Adam Smith", The European Journal of the History of Economic Thought 8 (2001): 1-29. 
przekonywali, że dobrze służąc Bogu, jednocześnie dobrze służą sobie i innym ludziom. W gronie tych osób, które czuły się na tyle oświecone, aby rozstać się z chrześcijańskimi wierzeniami, znaleźli się między innymi ci filozofowie i politycy, którzy - jak na przykład Antoine Nicolas Condorcet - odegrali znaczące role w rewolucji francuskiej w 1789 roku (wspomniany filozof był sekretarzem Francuskiego Zgromadzenia Narodowego $\mathrm{w}$ pierwszym okresie jego funkcjonowania). Jak wielkim uznaniem darzył on Voltaire'a, może świadczyć między innymi przedstawianie go jako najbardziej rozumnego i najbardziej sprawiedliwego ze wszystkich filozofów ${ }^{9}$. Był on współautorem przyjętej przez to Zgromadzenie w sierpniu 1789 roku Deklaracji praw człowieka i obywatela. Już jej pierwsze zdanie mówi o tym, że „ludzie rodzą się i pozostają wolni i równi co do praw", a kolejne przedstawiają ludzką wolność tak, jakby religia i religijności nie tylko nie były pomocne $\mathrm{w}$ realizowaniu wolności sumienia, myślenia, mówienia i upowszechnienia tego, co się ma do powiedzenia, ale wręcz stanowiły w tym przeszkodę $e^{10}$. Wprawdzie rewolucja francuska w 1789 roku dosyć szybko przeszła od słów do czynów (między innymi takich, jak odebranie Kościołowi katolickiemu we Francji jego wielkich dóbr i uczynienie sług Bożych sługami narodu) i stała się takim wielkim historycznym skandalem, jakim był jakobiński terror, jednak w dłuższej perspektywie przyczyniła się do głębokiej przemiany sumień zdecydowanej większości Francuzów, czego potwierdzeniem jest między innymi to, że dzisiaj niewielu z nich skłonnych jest występować w obronie chrześcijańskich wartości, a cały kraj z dumą obnosi się ze swoją laickością. Miał w tym pewien udział Voltaire, w co nie wątpią nie tylko Francuzi, lecz także zagraniczni znawcy francuskiej kultury. Warto dodać, że swoje uznanie dla Voltaire'a Francuzi wyrazili zarówno stawiając mu pomnik $\mathrm{w}$ paryskim Panthéonie (miejscu pochówku osób zasłużonych dla ich kraju), jak i nadając jego imię niejednej z placówek oświatowych.

Powiedzmy jednak jasno: raczej nikt nie rodzi się nieomylnym filozofem ani nawet takim, który wprawdzie od czasu do czasu się myli, ale nigdy w kwestiach najistotniejszych. Tej opinii nie podzielał jednak Voltaire, a w każdym razie wykluczał możliwość popełniania przez siebie błędu w ocenie takich religii, jak chrześcijaństwo, judaizm i islam. W okresie dojrzałym niechętnie zresztą przyznawał się do tego, że w czasie swojej edukacji w jezuickim Kolegium Ludwika Wielkiego do chrześcijańskich wierzeń i praktyk miał stosunek apologetyczny; przecież to spod jego pióra wyszła Oda na cześć świętej Genowefy, w której nie

9 Antoine Nicolas de Condorcet, „Vie de Voltaire”, w: Voltaire, Oeuvres complétes de Voltaire (Paris: Librairie de L. Hachette et Cie, 1859), 18.

10 Déclarations des droits de l'homme et du citoyen, in: Les déclarations des droits de l'homme de 1789 (Paris: Payot, 1988) 11. 
tylko nie kwestionował świętości tytułowej bohaterki, ale wręcz głosił jej chwałę. Na jego usprawiedliwienie można powiedzieć, że napisał ją w wieku szesnastu lat. Dojrzewanie Voltaire'a gwałtownie przyspieszyło w momencie, gdy zaczął bywać w środowisku paryskich libertynów. Miał ponoć wówczas nazywać Stary Testament „,nagromadzeniem opowieści i bajek”, apostołów "naiwnymi, łatwowiernymi idiotami”, a Ojców Kościoła „szarlatanami i oszustami"11. Takie zarzuty pojawiły się wprawdzie w donosie na policję i Voltaire wypierał się tych słów, jednak cała jego późniejsza twórczość pisarska w istotnym stopniu z nimi harmonizuje, a zawołanie Ecrasons l'infâme! („Rozdeptać to łajdactwo!”) nie tylko znakomicie wpisuje się w "poetykę" słowa tego autora, lecz także dobrze wyraża jego głęboką awersję do chrześcijaństwa, a w szczególności do katolicyzmu.

W ogromnym (liczącym ponad dwa tysiące pozycji) dorobku pisarskim Voltaire'a kwestia tradycyjnych religii i form religijności stanowi jeden z bardziej eksponowanych tematów. Z pełnym przekonaniem można powiedzieć, że twórca nie tylko żywił do nich głęboką awersję, ale także nie miał żadnych skrupułów, aby w ich krytyce sięgać po najbardziej drastyczne określenia. Przywołam tutaj tylko kilka przykładów. O chrześcijaństwie mówił, że jest „najbardziej absurdalną i najbardziej krwawą religia, jaka kiedykolwiek zainfekowała świat”, oraz "plagą nasłaną na człowieka przez autora wszelkiego zła"12. O Żydach napisał, że „od dawna jednoczą najbardziej plugawe chciwości z najbardziej obrzydliwymi przesądami i niezwyciężoną nienawiścią do każdego narodu, przez który są tolerowani i wzbogacani", oraz przypominał im, że „,składali Bogu krwawe ofiary z ludzi” i „byli potworami okrucieństwa i fanatyzmu w Palestynie". O mahometanach sądził natomiast, że ich prorok Mahomet był "fanatykiem, oszustem i obłudnikiem”, a o Koranie, że zawiera "sprzeczności, absurdy i anachronizmy”. Przedstawiam tutaj jedynie próbkę tych wypowiedzi, które pojawiają się na kartach jego Słownika filozoficznego (pierwsze wydanie ukazało się w 1776 roku). Nie można ich uznać za nieprzemyślane, poszczególne hasła były bowiem wielokrotnie przez Voltaire'a poprawiane i doskonalone z myślą o zadaniu możliwie najbardziej skutecznego ciosu tym religiom (pomysł napisania słownika pojawił się u Voltaire'a już w 1750 roku, a prace nad nim przyspieszyły po tym, jak we Francji i w innych europejskich krajach nasiliły się ataki na jezuitów).

W Słowniku znajduje się również hasło conscience. W języku francuskim termin ten oznacza zarówno świadomość, jak i sumienie. Voltaire uwzględnia oba jego znaczenia. Co więcej, wskazuje na występujący

11 René Pomeau, La Religion de Voltaire (Paris: Nizet, 1956).

12 Voltaire, „Christianisme”, w: Dictionnaire philosophique (Oxford: Voltaire Foundation, 1994-1995). 
między nimi merytoryczny związek. Wprawdzie w jego objaśnianiu wychodzi od przywołania autorytetu Locke'a (,wykazał on, że nie mamy ani idei, ani zasad wrodzonych"), jednak dosyć szybko przechodzi do przypomnienia chrześcijanom "masakry nocy świętego Bartłomieja” oraz tego, że „w świętych aktach wiary inkwizycji żadne sumienie mordercy nigdy nie wyrzucało sobie, że dokonał masakry mężczyzn, kobiet i dzieci”. Dalej dodaje, że wprawdzie „czysta religia, czysta moralność [...] tak kształtuje ludzką naturę, że od około siedmiu lat do szesnastu lub siedemnastu nie popełnia się złego czynu bez wyrzutów sumienia. Potem przychodzą gwałtowne namiętności, które zwalczają sumienie", jednak chrześcijaństwa nie można zaliczyć ani do „czystej religii”, ani też do „czystej moralności”.

Uzasadnienie dla tej oceny znajduje się w kolejnych partiach hasła. W drugiej jego części francuski filozof wychodzi od postawienia pytania: „czy sędzia ma osądzać według własnego sumienia, czy też na podstawie dowodów?" i przechodzi do przywołania opinii Tomasza z Akwinu - „wielkiego świętego, wielkiego teologa”, którego wielkość staje pod znakiem zapytania, gdy w jego Summie teologicznej Voltaire znajduje twierdzenie, że "sędzia musi głosić zgodnie z zarzutami i rzekomymi dowodami przeciwko oskarżonemu, którego niewinność jest mu doskonale znana". W trzeciej części tego hasła (O zwodniczym sumieniu) jego autor wychodzi od przypomnienia między innymi „,kilku obrazów Rembrandta" (żarliwego katolika, zaangażowanego nie tylko pędzlem na płótnie, ale także po stronie katolickiej Hiszpanii w okresie wojny trzydziestoletniej) i od razu przechodzi „do rzeczy”, czyli do stwierdzenia, że "sumienie i honor towarzyszą mu na pokaz, w zabawach, a zwłaszcza gdy hojnie płaci dziewczynie, którą utrzymuje". Istnieje jeszcze czwarta część hasła ( $O$ wolności sumienia). W roli głównej występuje w niej taki tajemniczy "kapelan księcia”, który nie mogąc dojść do porozumienia z anabaptysta, "grozi mu, że każe go powiesić", a na pytanie owego anabaptysty, ,"czy jest dominikaninem, jezuitą czy diabłem", odpowiada, że jest takim jezuita, który mówi jedynie to, co mu polecił powiedzieć jego zwierzchnik, „wielebny ks. Rektor”.

Opublikowanie Słownika wywołało ogromne oburzenie w różnych środowiskach chrześcijańskich. W Genewie uznany on został za dzieło „lekkomyślne, skandaliczne, bezbożne i niszczące Objawienie”. W Niderlandach nakazano jego spalenie na stosie. Potępił go również parlament Paryża, a Rzym umieścił je w 1765 roku na swoim Indeksie Ksiąg Zakazanych. Voltaire nie tylko nie przyznawał się do jego autorstwa, ale wręcz utrzymywał, że nie ma z nim nic wspólnego (co oczywiście nie przeszkadzało mu $\mathrm{w}$ dopisywaniu do kolejnych wydań dalszych, równie kąśliwych, uwag, sugestii i ocen). 


\section{Holbachowskie ujmowanie sumienia}

Raczej mało komu mogą kojarzyć się z religią i religijnością poglądy głoszone przez barona Paula Tiry'ego Holbacha (1723-1789) oraz tych, którzy gościli w jego paryskim salonie ${ }^{13}$. Ten mieszkający we Francji niemiecki arystokrata zyskał sławę nie tylko za sprawą organizowanych przez siebie spotkań, ale także, a nawet w głównej mierze, dzięki swojemu ateizmowi, który szerzył, nie przebierając w słowach. Paul Hazard twierdzi, że „nigdy nie było mu dosyć obelg pod adresem chrześcijaństwa. Do niezliczonych książek wymierzonych przeciwko religii dorzucał masowo inne, dostarczające tłumowi niewybrednej strawy antyklerykalnej"14. Spod jego pióra wyszły jednak nie tylko paszkwile na chrześcijaństwo, lecz także poważne traktaty filozoficzne. Jednym z nich jest System przyrody.

Pierwsza część tego dzieła została poświęcona prezentacji przyrody i jej praw, druga - analizie pochodzenia wiary w bóstwa i jej praktycznemu funkcjonowaniu. W jednej i w drugiej znaczącą rolę odgrywa człowiek. W pierwszej występuje w charakterze postaci pozytywnej, w drugiej - negatywnej, czyli jako osoba nie tylko wierząca w bóstwa lub Boga, ale także próbująca przekonać do tej wiary siebie i innych za pomocą "dowodów” na jego istnienie. Obie części łączy przekonanie ich autora, że wszystko to, co istniało, istnieje i będzie istnieć albo stanowi poruszającą się zgodnie z prawami mechaniki materię czy też jej pochodne. Ma do niej należeć również człowiek, łącznie z tym wyposażeniem, które ogólnie nazywa się dusza, a w szczegółach - zdolnością intelektualnego myślenia i emocjonalnego odczuwania, pragnienia czegoś i unikania czegoś innego itd. Na początku jednak przyroda „wysyła człowieka nagim i bezbronnym” i potrzeba czasu oraz wysiłków z jego strony, aby najpierw "odział się on w skórę zwierząt”, później "zaczął prząść złotą i jedwabną nić”, aż w końcu "pogrążył się w przepychu i wynajdowaniu codziennie tysięcy nowych potrzeb i odkrywaniu tysięcy nowych sposobów ich zaspakajania. [...] Wszystko, co przedsiębierzemy dla zmiany naszego bytu, stanowi ogromny łańcuch przyczyn i skutków będących jedynie rozwinięciem pierwotnych impulsów, które nadała nam przyroda"15.

${ }_{13}$ Phillipp Blom, Enlightening the world: Encyclopédie, the book that changed the course of history (New York, Palgrave Macmillan, 2005).

${ }_{14}$ Paul Hazard, Myśl europejska w XVIII wieku. Od Monteskiusza do Lessinga (Warszawa: PIW, 1972), 122.

${ }_{15}$ Paul Tiry Holbach, System przyrody, czyli prawa świata fizycznego i moralnego, przeł. Jadwiga Jabłońska, Halina Suwała (Warszawa: PWN, 1957), 55. 
Kwestia sumienia pojawia się w części pierwszej tego dzieła, jako część składowa teorii wolności człowieka. W jej świetle „na mózg człowieka działają często rozmaite i skomplikowane siły”, które „rozmaicie modyfikują go w różnych momentach życia" i sprawiają między innymi, że „zmieniają się jego upodobania, pragnienia i namiętności", a także pojawiają się takie wyobrażenia, które „wzbudzają niepokój zwany wstydem, żalem, wyrzutami sumienia". Te ostatnie stanowią

bolesne uczucia wzbudzane w nas przez przykrość, jaką nam sprawiają obecne lub przyszłe skutki naszych namiętności. Jeżeli skutki te są dla nas stale korzystne, to nie odczuwamy wcale wyrzutów sumienia; ale gdy tylko jesteśmy pewni, że nasze czyny narażają nas na nienawiść lub pogardę innych, albo gdy obawiamy się jakiejkolwiek kary, stajemy się niespokojni i niezadowoleni z siebie; wyrzucamy sobie nasze postępowanie, wstydzimy się go w głębi serca; obawiamy się sądu istot, na których szacunku, przychylności i życzliwość nam zależy... ${ }^{16}$

Może to się łączyć z wiarą w bóstwa lub Boga, jednak wiara taka sprawia, że człowiek „pogardza soba, nienawidzi siebie, sumienie jego jest wiecznie dręczone" i - co gorsza - nie zmienia on swojego postępowania (,w narodzie rozwiązłym nikt nie wstydzi się cudzołóstwa; w narodzie zabobonnym mord w imię poglądów nie wywoła na niczyim obliczu rumieńca wstydu").

W Systemie przyrody można jeszcze znaleźć jakieś przywołania sumienia, natomiast według rozprawy Holbacha zatytułowanej Etokracja, czyli rzad oparty na moralności człowiek albo go w ogóle nie posiada, albo też - jeśli nawet je posiada - to $\mathrm{w}$ gruncie rzeczy nie jest mu ono do niczego przydatne, również $\mathrm{w}$ moralności. Tytułowa etokracja ma oznaczać taki projekt „powiązania moralności z polityka, jak również z ideą ustawodawstwa zgodnego z cnota, które byłoby jednakowo korzystne dla panujących, narodów, rodzin i poszczególnych obywateli"17. Wiodąca rola w kreowaniu oraz we wprowadzaniu w życie tego projektu przypada oświeconemu rozumowi ustawodawców (,tylko ustawodawca oświecony rozumem i sprawiedliwością może przysporzyć sobie politycznych współpracowników”) i oświeconym rządzącym („w każdym rozumnym rządzie honor i cnota winny być nierozdzielne"). Występują $\mathrm{w}$ tej rozprawie sporadyczne wzmianki na temat sumienia (nie można jednak mieć całkowitej pewności, czy termin conscience oznacza tam nie sumienie, lecz świadomość), jednak są to tylko wzmianki. Co więcej, nawet tam, gdzie pojawia się jakieś jego przywołanie, wygląda ono tak, jakby autor chciał je wstydliwie ukryć za innymi siłami sprawczymi

16 Tamże, 281.

17 Paul Tiry Holbach, Etokracja, czyli rząd oparty na moralności, przeł. Marian Skrzypek (Warszawa: PWN, 1979), 3. 
ludzkich zachowań. Tak się rzecz ma między innymi w tym fragmencie, w którym jest mowa o „ożywionej dobrymi chęciami administracji, która przyznaje pisarzom wolność" i daje przyzwolenie na otwarte dyskusje: „tylko z dyskusji może się wyłonić zawsze pożyteczna dla ogółu prawda, która winna służyć za podstawę wszelkiej wiedzy ludzkiej. [...] Wolność myślenia, mówienia, pisania i publikowania może niepokoić tylko łotrów, tyranów, nieoświeconych i zepsutych ministrów, których intencje są sprzeczne $z$ dobrem publicznym albo którzy nie chca, aby ich wyprowadzano z błędu" ${ }^{\prime \prime}$.

\section{Obiekcje i ogólniejsze uwagi}

Zastrzeżenia i krytyczne uwagi zgłaszano wobec poglądów wszystkich przywołanych $\mathrm{w}$ tych rozważaniach oświeceniowych filozofów. Były one formułowane z różnych pozycji światopoglądowych, wyznaniowych i filozoficznych. Do Kantowskiego stawiania znaku równości między sumieniem i imperatywem kategorycznym zastrzeżenia miał między innymi Søren Kierkegaard. Jego zdaniem nie można tego zrobić, ponieważ to, co Kant nazywa imperatywem kategorycznym, może być uznane co najwyżej za imperatyw hipotetyczny, a co za tym idzie - nie może mieć tej mocy sprawczej, którą mu przypisywał królewiecki filozof $^{19}$. Z kolei Hannah Arendt w swojej książce pt. Eichmann in Jerusalem wskazywała na powoływanie się wymienionego w tytule hitlerowskiego zbrodniarza na ów Kantowski imperatyw, a przynajmniej na pragnienie zgodnego z nim postępowania ${ }^{20}$.

Smithowskie pojmowanie i przedstawianie sumienia niejednokrotnie łączono z opowiedzeniem się tego filozofa za takimi regułami kapitalistycznego gospodarowania, w których liczą się jedynie bogaci i ich pragnienie bogacenia się bez oglądania się na sytuacje życiowe biednych. Za taką ich wykładnia przemawiało nie tylko jego jednoznaczne opowiedzenie się za prowadzoną wówczas przez Wielką Brytanię polityką kolonialną (jeśli już zgłaszał do niej jakieś zastrzeżenia, to dotyczyły one nie sytuacji ludności w koloniach brytyjskich, lecz w metropolii), ale także poglądy głoszone przez takich jego bezpośrednich uczniów, jak Thomas Robert Malhus, autor dzieła O prawie narodów, w którym trudno byłoby znaleźć jakieś przejawy współczucia dla biednych ${ }^{21}$. Nie

18 Tamże, 122.

19 Ronald Green, Kierkegaard and Kant: The Hidden Debt (SUNY Press, 1992), 90 i n.

20 Hannah Arendt, Eichmann in Jerusalem: A Report on the Banality of Evil (London: Penguin Classics, 1963), 135-137.

21 Guido de Ruggiero, charakteryzując generalne przesłanie tego dzieła, pisze: „Twoja nędza, wydaje się mówić do klasy robotniczej - to twoja wina. Twoja 
brakuje jednak takich znawców poglądów Smitha, którzy uważają że pod takim postrzeganiem reguł społecznego życia on jednak by się nie podpisał. Należy do nich Anna Markwart, autorka książki Bogactwo uczuć moralnych. Wskazuje w niej jednak na inną kontrowersyjną kwestię związaną ze Smithowskim pojmowaniem sumienia. Dotyczy ona takiej jego istotnej części składowej, jaką jest sympatia („Smith podkreślał rolę naturalnej sympatii do bogatych i możnych dla zachowania harmonii społecznej"). Przywołuje ona przy tym opinie znawców poglądów Smitha, którzy uważają że takie postrzeganie sympatii jest produktem jego wyobraźni i istnieje jedynie intencjonalnie ${ }^{22}$.

Nie będę tutaj wyliczał tych obiekcji i krytycznych uwag, które były zgłaszane do poglądów Voltaire'a i Holbacha. Nie tylko dlatego, że ich lista jest długa i zróżnicowana, ale także dlatego, że są one na ogół znane, a przynajmniej wiadomo, z jakich pozycji były i są zgłaszane. Chciałbym natomiast sformułować kilka uwag do ich postrzegania i przedstawiania sumienia. Jeśli zatem chodzi o Holbacha, to jestem przekonany, że nie najlepszym pomysłem jest takie traktowanie ludzkiego sumienia, jakby go w ogóle nie było lub jakby było ono czymś tak mało istotnym, że w gruncie rzeczy nie ma o czym mówić. Inaczej rzecz ujmując, nie jest zadowalającym rozwiązaniem problemu istotnych regulatorów ludzkiego postępowania postawienie całej „stawki" na przyrodę oraz nadzieję, że tak wpłynie ona na nasze postępowania, iż będą one efektywne i sprawiedliwe. Jest raczej rzeczą oczywista, że przyrodnicze uwarunkowania czasami skłaniają do dobrego, a czasami do złego i trudno jest przewidzieć, kiedy górę weźmie to pierwsze, a kiedy to drugie. Nie będę tutaj podawał żadnych przykładów. Powiem jedynie, że oświeceniowa wiara w tak zwanego dobrego dzikusa, czyli osobnika "nieskażonego" cywilizacyjnymi grzechami, już w tamtej epoce była uznawana za naiwność ${ }^{3}$. Problem zatem nie sprowadza się do hamletowskiego pytania: mówić czy nie mówić o sumieniu i jego roli w kreowaniu życia i współżycia

nieprzezorność i brak samokontroli doprowadziły cię do punktu, w którym nasila się zbrodnicza rywalizacja. Mylisz się, obwiniając swoich panów, którzy dzielą z tobą niepożądane efekty twojego błędu. Na co zdałby się marny podatek, gdyby nie podatek pieniężny płacony przez bogaczy, który wspiera rozrzutność biedoty i daje zachętę do wzrostu populacji ludzkiej?". Guido de Ruggiero, The History of European Liberalism (Boston: 1959), 110.

${ }^{22}$ „Harmonia społeczna jest nie tylko efektem instynktownych zachowań. Opiera się ona na naturalnej sympatii będącej podstawą więzi społecznych, życzliwości uczuć pomiędzy członkami rodziny czy przyjaciółmi, poczucia tożsamości grupowej". Anna Markwart, Bogactwo uczuć moralnych. Jednostka i społeczeństwo we wzajemnych oddziaływaniach w perspektywie filozofii Adama Smitha (Toruń: Wydawnictwo Naukowe UMK, 2017), $67 \mathrm{i} \mathrm{n.}$

${ }^{23}$ Por. Jan Jakub Rousseau, „O pochodzeniu i podstawach nierówności między ludźmi”, w: tenże, Trzy rozprawy z filozofii społecznej, przeł. Henryk Elzenberg (Warszawa: PWN, 1956), 181 i n. 
ludzkiego? (przynajmniej dla mnie jest oczywiste, że należy o nim mówić), lecz do pytań: co i jak o nim mówić? Nie jest jedyną możliwością takie mówienie o nim, jakie proponują i praktykują od wieków chrześcijańscy teolodzy. Jego swoiste „alter ego" stanowi ten typ narracji, który proponowali i stosowali Voltaire i Holbach. Być może narażę się współczesnym deistom, agnostykom i ateistom, mówiąc, że wprawdzie może ono okazać się pomocne w wyzbywaniu się tradycyjnych religijnych wierzeń, lecz może także prowadzić do „okopywania” się ich zwolenników na swoich pozycjach i nieprzyjmowania do wiadomości żadnego z argumentów przeciwników.

Mam nadzieję, że sformułowanie przeze mnie tych ogólniejszych uwag nie zostanie potraktowane jako opowiedzenie się po stronie obrońców chrześcijańskiego myślenia i mówienia o sumieniu. Nie tylko nie poczuwam się do takiej roli, ale także niejedno miałbym do powiedzenia na temat nadużyć popełnianych przy przyzwoleniu tego sumienia. Dzisiaj nagłaśnia się pedofilię w Kościele. Lista takich nagannych czynów chrześcijan jest jednak o wiele dłuższa i znacznie bardziej zróżnicowana. Kiedyś mówił o nich Voltaire, dziś piętnują je nie tylko zdeklarowani wolterianie, ale także wielu tych, którzy są dalecy od podziwu dla francuskiego filozofa, jak również tych, którzy kontynuują jego myśl dotyczącą tradycyjnej religii i religijności. Wśród demaskatorów różnego rodzaju nieprawidłowości i nieprawości chrześcijan nie brakuje osób głęboko wierzących, w tym osób duchownych; nie będę ich tutaj wymieniał, są one bowiem powszechnie znane. Płynie z tego taki wniosek, że ważne jest nie tyle to, czy się mówi, czy też nie mówi o sumieniu, ile to, jak się realizuje jego nakazy oraz - co zresztą z tym pierwszym bezpośrednio się wiąże - czy znajduje się w nim, czy też nie znajduje usprawiedliwienia dla naruszeń tych nakazów.

Na koniec kilka uwag związanych z narracją o sumieniu. Pierwsza z nich dotyczy różnicy i granicy między sumieniem filozofów i sumieniem według filozofów. W tych rozważaniach eksponowałem to drugie spojrzenie. Trzeba jednak jasno powiedzieć, że te różnice i granice były i są niejednokrotnie płynne; czasami łatwiej jest je konkretyzować $w$ tym pierwszym ujęciu, a czasami w drugim. W tych przypadkach, w których minimalizuje się rolę sumienia i maksymalizuje rolę takich regulatorów ludzkich zachowań jak przyroda czy instytucje porządku publicznego, w gruncie rzeczy pozostaje ten drugi sposób jego przedstawiania. Druga $\mathrm{z}$ tych uwag wiąże się nie z minimalizowaniem roli sumienia, lecz z jej maksymalizowaniem oraz jej realizowaniem w konkretnym życiu. Stwierdzenie, że jest ono udziałem ludzi głęboko religijnych, okazuje się tylko częściowo trafne. Trzeba jasno powiedzieć, że takie osoby zajmują niejednokrotnie eksponowane miejsce w Kościele, a czasami - jak na przykład w przypadku św. Franciszka - stają się wzorami dla wielu późniejszych pokolen. $W$ gronie maksymalizujących znaczenie sumienia 
znajdują się niewątpliwie również takie postaci, wobec których religijności można mieć wątpliwości. Nie wolno jednak zapominać, że w sytuacji, gdy spotykały się one i spotykają z ludzkim nieszczęściem, gotowe były i są do udzielania pomocy, a nawet do największych poświęceń. Myślę tutaj nie tylko o okazjonalnych społecznikach angażujących się w działalność pomocową ludności regionów świata dotkniętych wojnami, epidemiami i innymi zagrożeniami, ale także o tych osobach, które w swoim życiu i współżyciu z innymi nie chcą lub nie potrafią przejść obojętnie wobec potrzebujących pomocy. Czasami kierują się oni odruchem serca, niekiedy zaś zrozumieniem zaistniałych okoliczności, a jeszcze kiedy indziej takim wyrachowaniem, które wyraża się w formule: „Dzisiaj ja pomagam innymi, a w przyszłości być może sam będę potrzebował pomocy". Nie chciałbym oceniać żadnej z tych motywacji. Skłonnym jestem jednak twierdzić, że w każdej z nich potrzebny jest jakiś rodzaj wrażliwego sumienia.

Niewątpliwie nie zawsze można oczekiwać od sumienia skłaniania do takiego działania, które sprawia, że bilans tego, co się daje, oraz tego, co się dostaje w zamian, jest dodatni. Można jednak, a być może nawet należy, oczekiwać od niego współpracy z ludzkim rozumem. Naiwnością byłoby sądzić, że taka współpraca będzie w każdym przypadku łatwa czy zgodna. Co więcej, należy raczej spodziewać się, że dojdzie między nimi do różnego rodzaju „spięć" i „napięć”, a nawet do wzajemnego kwestionowania swoich mocy wykonywania zadań, przy czym zewnętrzne okoliczności mogą dawać argumenty obu stronom. Posłużę się tutaj tylko jednym przykładem. Bestialstwa II wojny światowej przemawiają za słusznością twierdzenia tych, którzy uważają że zarówno w zachowaniach jednostkowych, jak i zbiorowych sumienie albo zupełnie milczało, albo też jego głos był tak słaby, że nie może stanowić tematu dyskusji. Natomiast mające wówczas miejsce przypadki niesłychanego heroizmu i poświęcenia (na przykład poświęcenie przez Maksymiliana Marię Kolbego swojego życia za współwięźnia w obozie koncentracyjnym w Oświęcimiu) dostarczają argumentów przemawiających za tym, że nawet $w$ najbardziej dramatycznych okolicznościach sumienie potrafi ujawnić swoją kierowniczą moc. Chcę przez to powiedzieć nie tylko to, że jest o czym dyskutować, ale przede wszystkim ponownie podkreślić, iż nie jestem skłonny solidaryzować się z tymi, którzy negują lub minimalizują rolę ludzkiego sumienia.

\section{Bibliografia}

Arendt Hannah. 1963. Eichmann in Jerusalem: A Report on the Banality of Evil. London: Penguin Classics. 
Blom Philipp. 2005. Enlightening the world: Encyclopédie, the book that changed the course of history. New York: Palgrave Macmillan.

Condorcet Antoine Nicolas. 1859. Vie de Voltaire. W: Oeuvres complétes de Voltaire. Paris.

Green Ronald. 1992. Kierkegaard and Kant: The Hidden Debt. New York: SUNY Press.

Hazard Paul. 1972. Myśl europejska w XVIII wieku od Monteskiusza do Lessinga, przeł. Halina Suwała. Warszawa: PIW.

Hill Luis. 2001. „The hidden theology of Adam Smith”. The European Journal of the History of Economic Thought 8, 1: 1-29.

Holbach Paul Tiry. 1979. Etokracja, czyli rzad oparty na moralności, przeł. Marian Skrzypek. Warszawa: PWN.

Holbach Paul Tiry. 1957. System przyrody, czyli prawa świata fizycznego i moralnego, przeł. Jadwiga Jabłońska, Halina Suwała. Warszawa: PWN.

Kant Immanuel. 1957. Krytyka czystego rozumu, przeł. Roman Ingarden. Warszawa: PWN.

Kant Immanuel. 2005. Metafizyka moralności, przeł. Ewa Nowak. Warszawa: Wydawnictwo Naukowe PWN.

Kant Immanuel. 2005. Odpowiedź na pytanie: czym jest oświecenie, przeł. Tomasz Kupś. W: Immanuel Kant. Rozprawy z historii filozofii. Kęty: Wydawnictwo Antyk.

Les déclarations des droits de l'homme de 1789 (ed.). 1988. Paris: Payot.

Markwart Anna. 2017. Bogactwo uczuć moralnych. Jednostka i społeczeństwo we wzajemnych oddziatywaniach w perspektywie filozofii Adama Smitha. Toruń: Wydawnictwo Naukowe Uniwersytetu Mikołaja Kopernika.

Pomeau René. 1956. La Religion de Voltaire. Paris: Nizet.

Rahner Karl, Vorgrimler Herbert. 1987. Mały słownik teologiczny, przeł. Tadeusz Mieszkowski, Paweł Pachciarek. Warszawa: Pax.

Rousseau Jan Jakub. 1956. Trzy rozprawy z filozofii społecznej, przeł. Henryk Elzenberg. Warszawa: PWN.

Smith Adam. 1954. Badania nad natura i przyczynami bogactwa narodów, przeł. Oswald Einfeld, Stefan Wolff. Warszawa: PWN.

Smith Adam. 1989. Teoria uczuć moralnych, przeł. Danuta Petsch. Warszawa: PWN.

Voltaire. 1994-1995. Dictionnaire philosophique. Oxford: Voltaire Foundation.

Zatorski Włodzimierz ks. (OSB). 2006. Dar sumienia. Kraków: Wydawnictwo Benedyktynów.

\section{Streszczenie}

W artykule przywołuję rozumienie zagadnienia sumienia czterech znaczących przedstawicieli Oświecenia: I. Kanta, A. Smitha, Voltaire'a i P. T. Holbacha. Kwestia została podjęta w pierwszej kolejności przez starożytnych filozofów, następnie przez teologów chrześcijańskich; później zaś zajmowali się nią oświeceniowi myśliciele. Wspomniani filozofowie analizowali ją jednak w opozycji do 
obu - pierwszej i drugiej tradycji. Zaproponowali takie rozwiązania, które były ich zdaniem znacznie bardziej racjonalne, choć między sobą bardzo się różniły. Każde z nich było na swój sposób nowatorskim i inspirującym punktem wyjścia do poważnych dyskusji.

Słowa kluczowe: sumienie, Kant, Smith, Voltaire, Holbach

\section{Conscience According to Enlightenment Philosophers}

\section{Summary}

In these remarks I recall the understanding and presentation of the issue of conscience by the three significant representatives of the Enlightenment, i.e. I. Kant, A. Smith, Voltaire and P. T. Holbach. First of all, it was undertaken by ancient philosophers, then by Christian theologians, and finally by the philosophers of the Enlightenment. However, the philosophers recalled here had analyzed it in opposition to both - the first and the latter tradition. They had proposed such solutions that were in their opinion much more rational, yet they differed significantly. Nevertheless, each of them was an innovative and inspiring starting point for serious discussions.

Keywords: conscience, Kant, Smith, Voltaire, Holbach 